\title{
PROSPECTIVE STUDY OF BACTEREMIA RATE AFTER ELECTIVE BAND LIGATION AND SCLEROTHERAPY WITH CYANOACRYLATE FOR ESOPHAGEAL VARICES IN PATIENTS WITH ADVANCED LIVER DISEASE
}

\author{
Danielle Queiroz BONILHA ${ }^{1}$, Lucianna Motta CORREIA ${ }^{1}$, Marie MONAGHAN ${ }^{2}$, \\ Luciano LENZ ${ }^{1,3}{ }^{3}$, Marcus SANTOS ${ }^{1}$ and Ermelindo DELLA LIBERA ${ }^{1,3}$
}

\begin{abstract}
Context - Band ligation (BL) is the most appropriate endoscopic treatment for acute bleeding or prophylaxis of esophageal variceal bleeding. Sclerotherapy with N-butyl-2-cyanoacrylate (CY) can be an alternative for patients with advanced liver disease. Bacteremia is an infrequent complication after BL while the bacteremia rate following treatment with $\mathrm{CY}$ for esophageal varices remains unknown. Objectives - To evaluate and compare the incidence of transient bacteremia between cirrhotic patients submitted to diagnostic endoscopy, $\mathrm{CY}$ and BL for treatment of esophageal varices. Methods - A prospective study comprising the period from 2004 to 2007 was conducted at Hospital of Universidade Federal de São Paulo, UNIFESP, SP, Brazil. Cirrhotic patients with advanced liver disease (Child-Pugh B or C) were enrolled. The patients were divided into two groups according treatment: BL Group (patients undergoing band ligation, $\mathrm{n}=20$ ) and CY Group (patients receiving cyanoacrylate injection for esophageal variceal, $\mathrm{n}=$ 18). Cirrhotic patients with no esophageal varices or without indication for endoscopic treatment were recruited as control (diagnostic group $\mathrm{n}=20$ ). Bacteremia was evaluated by blood culture at baseline and 30 minutes after the procedure. Results - After 137 scheduled endoscopic procedures, none of the 58 patients had fever or any sign suggestive of infection. All baseline cultures were negative. No positive cultures were observed after CY or in the control group - diagnostic endoscopy. Three (4.6\%) positive cultures were found out of the 65 sessions of band ligation $(P=0.187)$. Two of these samples were positive for coagulase-negative staphylococcus, which could be regarded as a contaminant. The isolated microorganism in the other case was Klebsiella oxytoca. The patient in this case presented no evidence of immunodeficiency except liver disease. Conclusions - There was no significant difference in bacteremia rate between these three groups. BL or CY injection for non-bleeding esophageal varices may be considered as low-risk procedures regarding bacteremia even when performed on patients with advanced liver disease.
\end{abstract}

HEADINGS - Bacteremia. Ligation. Sclerotherapy. Cyanoacrylates. Esophageal and gastric varices. Liver diseases.

\section{INTRODUCTION}

Bacterial translocation of endogenous microbial flora into the bloodstream may occur during any endoscopic procedure $^{(2)}$. The mean frequency of bacteremia is $4.2 \%$ after diagnostic esophagogastroduodenoscopy. This rate can be higher following therapeutic procedures ${ }^{(10,14)}$. Moreover, patients with chronic liver disease (especially in advanced stages) are more predisposed to bacteremia and infections secondary to their immunocompromised state $^{(9,12)}$.

Band ligation (BL) is the most appropriate endoscopic treatment for acute bleeding or primary and secondary prophylaxis of esophageal variceal bleeding ${ }^{(7)}$. N-butyl-2-cyanoacrylate $(\mathrm{CY})$ is used worldwide to arrest bleeding from gastric varices and differs from conventional sclerosants because it polymerizes within seconds on contact with aqueous media $^{(3)}$. Furthermore, studies have demonstrated the usefulness of $\mathrm{CY}$ injection for the treatment of bleeding or no bleeding esophageal varices, especially in ChildPugh C cirrhotic patients ${ }^{(11)}$. It has been suggested that CY forms a barrier in tissue that prevents bacterial invasion. However, the risk of bacteremia in patients receiving $\mathrm{CY}$ injection for esophageal varices is still unknown $^{(3,17)}$.

Despite the widespread use of BL and CY, no studies have compared the risk of bacteremia between patients submitted to BL and those receiving CY for prophylaxis of variceal bleeding. For that reason, the objective of

There was no financial support for this study.

The authors have no conflict of interest to disclose.

${ }^{1}$ Universidade Federal de São Paulo (UNIFESP), SP, Brasil; ${ }^{2}$ King's College London School of Medicine, London, England; ${ }^{3}$ Laboratório Fleury, São Paulo, SP, Brasil;

Correspondence: Dr. Danielle Queiroz Bonilha - Rua Aquilina Bonatti Malavazzi, 354 - 13140-000 - Paulínia, SP, Brazil. E-mail: daniellerossana@hotmail.com 
the present prospective study was to evaluate and compare the incidence of transient bacteremia between diagnostic endoscopy (DE), CY and BL in advanced cirrhosis.

\section{METHODS}

A prospective study comprising the period from November 2004 to May 2007 was conducted at Hospital of Universidade Federal de São Paulo, UNIFESP, São Paulo, SP, Brazil. Cirrhotic patients with advanced liver disease (Child-Pugh B or C), ranging in age from 18 to 75 years were enrolled. Cirrhosis was diagnosed and staged by physical examination, biochemical tests, imaging studies, and/or histological analysis.

Excluded from the study were patients in American Society of Anesthesiology physical status IV or V, patients submitted to emergency procedures, patients who presented with infection or had been taking antibiotics at any point in the last 4 weeks, patients with non cirrhotic portal hypertension, and patients who did not sign the informed consent form.

Due to the substantial case load required, it was decided to limit the study to 60 cases and their respective procedures.

The study was conducted in accordance with the World Medical Association Declaration of Helsinki - Ethical Principles for Medical Research Involving Human Subjects and was approved by the Ethics Review Committee of our University (number 1244/04). A written informed consent was obtained from all patients.

Patients with an indication of endoscopic treatment for esophageal varices were randomized using sealed and opaque envelopes to allocate then in BL or CY group. Patients without esophageal varices or varices without indication for therapeutic intervention were recruited as controls (DE group).

\section{Endoscopic procedures/interventions}

\section{Control group (diagnostic endoscopy - DE)}

All endoscopic procedures were performed with the standard technique. Single-channel gastroscopes (Olympus Optical Co, Ltd, Tokyo, Japan) and intravenous sedation with individual doses of midazolam, fentanyl and propofol were used. Patients without esophageal varices or varices without indication for therapeutic intervention were included in this group.

\section{Band ligation ( $B L)$}

BL of varices, in planned schedule, was performed with a reusable multiple-band ligator Euroligator ${ }^{\circledR}$ (WMT, Inc., Wiesbaden, Germany $)^{(5)}$. All varices were treated during each session using three to six bands. The procedure was repeated at intervals of 3 weeks until the varices were completely resolved.

\section{N-butyl-2-cyanoacrylate injection (CY)}

The procedure was performed with a 23-gauge disposable needle injector (EIS 01943, Top Co., Tokyo, Japan) introduced through the accessory channel. The esophageal varices were injected with a 1:1 mixture of $0.5 \mathrm{~mL} \mathrm{~N}$-butyl-cyanoacrylate
(Histoacryl glue ${ }^{\circledR}$, Braun, Melsungen, Germany) and 0.5 $\mathrm{mL}$ Lipiodol (Guerbet Laboratory, Villepinte, France). The mixture of cyanoacrylate and Lipiodol was prepared under aseptic conditions by assistant wearing sterile disposable gloves. During each elective session, two varices received intra variceal injections of the mixture and the procedure was repeated at intervals of 2 weeks until obliteration. A plain radiograph of the chest was obtained from all patients within 2 hours after endoscopic treatment to determine the intra variceal injection of CY.

\section{Evaluation of bacteremia}

Bacteremia was evaluated by blood culture at baseline and 30 minutes after the procedure. The skin was cleaned with $70 \%$ isopropyl alcohol and $10 \mathrm{~mL}$ blood was collected. The BACTEC ${ }^{\circledR}$ system (BD Bactec plus Aerobic/F, Becton, Dickinson and Company, County Clare, Ireland) was used for blood culture. A negative result was defined as no significant growth after incubation for 7 days and no growth in the terminal subculture.

The patients were closely monitored (axillary temperature, blood pressure, heart and respiratory rates) for at least 3 hours after the procedure. To evaluate symptoms associated with infection, the patients were contacted by telephone 24-48 hours after hospital discharge. The subjects were instructed to return or call the unit in the event of any adverse symptoms at any time.

\section{Statistical analysis}

Numerical variables are reported as means \pm standard deviation (SD). Differences were analyzed by the Student $t$-test. Qualitative variables are expressed as frequencies and percentages. For categorical variables comparisons, Pearson's chi-square or Fischer's were used when indicated. A level of significance of 0.05 was adopted. All data analyses were performed with the SPSS for Windows program, version 16.0.

\section{RESULTS}

A total of 137 scheduled endoscopic procedures and 60 patients were included in the study. Two patients were excluded because of concomitant infection (urinary tract and spontaneous bacterial peritonitis). There were 20 patients in the BL group, 18 in the CY group, and 20 in the control group. In the BL group, the mean number of sessions was $3.20 \pm 1.47$ (range: 1 to 7 sessions). In the CY group, the mean number of sessions was $2.83 \pm 1.29$ (range: 1 to 5 sessions).

The demographic characteristics of the patients were similar in the three groups (Table 1). There was a predominance of men in all groups. The cause of cirrhosis was viral hepatitis or alcohol abuse in most cases. The caliber of varices and presence of red wale marks were similar in the $\mathrm{BL}$ and $\mathrm{CY}$ groups. There were also no differences in Child-Pugh class or MELD score between groups.

All cultures obtained before the endoscopic procedures were negative. No positive cultures were observed after CY or 
TABLE 1. Demographics characteristics of groups

\begin{tabular}{|c|c|c|c|c|}
\hline \multicolumn{5}{|c|}{ Group } \\
\hline Characteristics & $\begin{array}{c}\text { Band } \\
\text { Ligation (n) }\end{array}$ & $\begin{array}{c}\text { Cianoacrylate } \\
\text { (n) }\end{array}$ & $\begin{array}{c}\text { Control } \\
(\mathrm{n})\end{array}$ & $P$ \\
\hline $\begin{array}{l}\text { Age in years } \\
\text { (mean } \pm \text { SD) }\end{array}$ & $52.30 \pm 12.64$ & $51.11 \pm 8.17$ & $51.35 \pm 11.13$ & ND \\
\hline Male sex $(\%)$ & $15(75)$ & $15(83.3)$ & $18(90)$ & ND \\
\hline \multicolumn{5}{|c|}{ Child-Pugh classification } \\
\hline $\mathrm{B}(\%)$ & $15(75)$ & $15(83.3)$ & $16(80)$ & ND \\
\hline $\mathrm{C}(\%)$ & $5(25)$ & $3(16.7)$ & $4(20)$ & \\
\hline $\begin{array}{l}\text { MELD } \\
\text { classification } \\
(\text { mean } \pm S D)\end{array}$ & $10.95 \pm 3.15$ & $11.33 \pm 4.29$ & $12.60 \pm 5.04$ & ND \\
\hline \multicolumn{5}{|l|}{ Etiology (\%) } \\
\hline Alcohol & $6(30)$ & $7(38.9)$ & $5(25)$ & \\
\hline Viral & $6(30)$ & $9(50)$ & $10(50)$ & \\
\hline Viral + alcohol & $3(15)$ & $1(5.6)$ & $2(10)$ & \\
\hline Other & $5(25)$ & $1(5.6)$ & $3(15)$ & \\
\hline
\end{tabular}

$\mathrm{SD}=$ standard deviation

in the DE group. Positive cultures were found in $3(4.6 \%)$ of 65 sessions of band ligation $(P=0.187)$. Coagulase-negative staphylococci were the organisms identified in two of these cultures, suggestive of contamination. In the other case, the culture of a 53-year-old man (Child-Pugh class B) was positive for Klebsiella oxytoca. The patient was submitted to another session 3 weeks later and the blood culture was negative from that time. The patient presented no evidence of immunodeficiency, except for his liver disease.

Complications such as major bleeding, stenosis, peritonitis or perforation did not occur in this study. Some patients experienced mild post-procedure dysphagia.

\section{DISCUSSION}

There are no studies in the literature comparing the incidence of bacteremia after BL of esophageal varices and CY for esophageal varices in cirrhotic patients. In the present study, bacteremia was observed in $3(4.6 \%)$ of 65 sessions of $\mathrm{BL}$, whereas no positive cultures were obtained after $\mathrm{CY}$ or for control patients.

This study has some limitations. The sample size was relatively small and the true frequency of bacteremia associated with DE, BL or CY might be underestimated because of the risk of not detecting transient bacteremia when only a single post-procedure blood sample is analyzed.

In two cases of positive culture, the bacterium isolated was Staphylococcus hominis, a coagulase-negative staphylococcus. Despite some reports of Staphylococcus hominis strains causing nosocomial bloodstream infection ${ }^{(15)}$ and the recognition that coagulase-negative staphylococcus can cause clinically significant infections ${ }^{(18)}$, these bacteria might be regarded as contaminants. This suggestion is based on the fact that coagulase-negative staphylococcus are one of the most frequent causes of blood culture contamination ${ }^{(18)}$, and because these patients presented no clinically significant alterations. The other case, a different microorganism was isolated after third BL session. The pathogen was Klebsiella oxytoca, a metallo-beta-lactamase-producing Enterobacteriaceae ${ }^{(1)}$. This microorganism can cause various infectious complications in both healthy and immunocompromised subjects, such as port central venous catheter-associated bloodstream infection $^{(13)}$, spontaneous peritonitis ${ }^{(16)}$ and malignant external otitis $^{(6)}$, and was recently described as the causative agent of antibiotic-associated hemorrhagic colitis ${ }^{(8)}$. The last condition is usually preceded by antibiotic treatment with penicillin and is more common in childhood. To our knowledge, this is the first case of Klebsiella oxytoca bacteremia after an endoscopic procedure. The present patient was not treated with antibiotics and did not show any signs or symptoms of infection during follow-up.

BL has been associated with bacteremia rates of $1 \%$ to $25 \%$, with a mean rate of $8.8 \%{ }^{(2)}$. The incidence of bacteremia after BL in the present study is similar that was found in another research performed in your service, 13 years ago $(5.7 \%)^{(4)}$. A review investigating the association between $\mathrm{BL}$ and bacteremia showed that the latter was more frequent among patients with severe liver disease. Therefore, liver dysfunction has been suggested to be an independent risk factor, but there are others studies that do not support this suggestion $^{(5)}$. This finding was also not confirmed in the present study because all patients had advanced liver disease and only one patient presented with a positive blood culture and this patient was of Child-Pugh class B status.

Several studies have evaluated the frequency and clinical outcome of bacteremia in patients with bleeding and nonbleeding gastric varices who received endoscopic CY. Chen et al. ${ }^{(3)}$ detected post-procedure positive cultures in $15(31.9 \%)$ of 47 patients treated during acute bleeding of gastric varices. This rate is comparable to that reported for endoscopic injection sclerotherapy for esophageal varices. In another study, none of the patients who underwent elective CY injection for gastric varices developed bacteremia. In contrast, a significantly higher rate of bacteremia was observed in patients who presented for emergency $\mathrm{CY}$ to control bleeding of gastric varices $(15 \%$ at 5 minutes and $10 \%$ at 3 hours $)^{(11)}$. However, the present study was not designed to compare rates of bacteremia before and after emergency endoscopy.

A meta-analysis indicated a significant beneficial effect of antibiotic prophylaxis in decreasing the incidence of bacterial infections and mortality in patients with cirrhosis who develop gastrointestinal bleeding ${ }^{(2)}$, and most of this group are submitted to endoscopic therapy. Therefore, the risk of transient bacteremia differs between emergency and elective situations. Patients with active or recent bleeding are more susceptible to bacterial invasion through a defective variceal wall ${ }^{(11)}$. These patients usually develop bacteremia even before endoscopic therapy. On the other hand, the occurrence of bacteremia, subsequent to planned procedures for esophageal varices, is relatively rare and perhaps without clinically importance, even in patients with advanced liver disease. 


\section{CONCLUSION}

The results of the present study indicated that bacteremia incidences associated with elective $\mathrm{BL}$ or
CY for esophageal varices are equally rare. Therefore, both techniques can be considered low-risk procedures regarding infection even when performed on patients with advanced cirrhosis.

Bonilha DQ, Correia LM, Monaghan M, Lenz L, Santos M, Della Libera E. Estudo de bacteriemia relacionada à ligadura elástica versus injeção de cianocrilato para varizes esofágicas em pacientes com doença hepática avançada. Arq Gastroenterol. 2011;48(4):248-51.

RESUMO - Contexto - A ligadura elástica é considerada o melhor tratamento endoscópico para o sangramento agudo por varizes esofágicas ou para profilaxia do sangramento varicoso, sendo a escleroterapia com N-2-butil-cianoacrilato uma alternativa para os pacientes com doença hepática avançada e distúrbio de coagulação. Bacteriemia é uma complicação rara associada à ligadura elástica, por outro lado, a incidência de bacteriemia relacionada com o uso de N-2-butil-cianoacrilato permanece desconhecida. Objetivos - Avaliar e comparar a incidência de bacteriemia transitória entre os pacientes cirróticos submetidos a endoscopia digestiva alta diagnóstica, escleroterapia com N-2-butil-cianoacrilato ou ligadura elástica para tratamento das varizes esofágicas. Métodos - Estudo prospectivo realizado entre 2004 e 2007 foi conduzido no Hospital da Universidade Federal de São Paulo, UNIFESP, Brasil. Cirróticos com doença hepática avançada (Child B ou C) foram incluídos. Os pacientes foram divididos em dois grupos de acordo com o tratamento: grupo ligadura elástica (pacientes submetidos a ligadura elástica, $\mathrm{n}=20$ ) e grupo N-2-butil-cianoacrilato (pacientes submetidos a injeção de N-2-butil-cianoacrilato, $\mathrm{n}=18$ ). Cirróticos sem varizes esofágicas ou com varizes esofágicas sem indicação de tratamento endoscópico foram recrutados como controles (grupo endoscopia diagnóstica, $\mathrm{n}=20$ ). Bacteriemia foi avaliada por hemocultura basal e 30 minutos após o procedimento. Resultados - Dos 137 procedimentos endoscópicos realizados, nenhum dos 58 pacientes apresentou febre ou qualquer sinal sugestivo de infecção. Todas as hemoculturas de base foram negativas. Nenhuma cultura positiva foi observada após o uso de N-2-butil-cianoacrilato ou no grupo controle. Três $(4,6 \%)$ culturas positivas foram encontradas após as 65 sessões de ligadura elástica $(P=0,187)$. Duas dessas foram positivas para Staphylococcus coagulase-negativo, provavelmente relacionadas à contaminação. O microorganismo isolado no terceiro caso foi Klebsiella oxytoca. Nesse caso, o paciente apresentava a própria doença hepática como única situação relacionada à imunodeficiência. Conclusões - Não houve diferença significante na incidência de bacteriemia entre os três grupos de pacientes. Ligadura elástica ou injeção de N-2-butil-cianoacrilato para profilaxia do sangramento varicoso podem ser considerados procedimentos de baixo risco quanto ao surgimento de bacteriemia, mesmo em pacientes com doença hepática avançada.

DESCRITORES - Bacteriemia. Ligadura. Escleroterapia. Cianoacrilatos. Varizes esofágicas e gástricas. Hepatopatias.

\section{REFERENCES}

1. Aschbacher R, Pagani L, Doumith M, Pike R, Woodford N, Spoladore G, Larcher C, Livermore DM. Metallo-beta-lactamases among Enterobacteriaceae from routine samples in an Italian tertiary care hospital and long-term care facilities during 2008. Clin Microbiol Infect. 2010;17:181-9.

2. ASGE Standards of Practice Committee; Banerjee S, Shen B, Baron TH, Nelson DB, Anderson MA, Cash BD, Dominitiz JA, Gan SI, Harrison ME, Ikenberry SO, Jagannath SB, Lichtenstein D, Fanelli RD, Lee K, van Guilder T, Stewart LE. Antibiotic prophylaxis for gastrointestinal endoscopy. Gastrointest Endosc. 2008;67:791-8.

3. Chen WC, Hou MC, Lin HC, Yu KW, Lee FY, Chang FY, Lee SD. Bacteremia after endoscopic injection of N-butyl-2-cyanoacrylate for gastric variceal bleeding. Gastrointest Endosc. 2001;54:214-8.

4. da Silveira Rohr MR, Siqueira ES, Brant CQ, Morais M, Libera ED Jr, Castro RR, Ferrari AP. Prospective study of bacteremia rate after elastic band ligation and sclerotherapy of esophageal varices in patients with hepatosplenic schistosomiasis. Gastrointest Endosc. 1997;46:321-3.

5. Ell C, May A, Wurster H. The first reusable multiple-band ligator for endoscopic hemostasis of variceal bleeding, nonvariceal bleeding and mucosal resection. Endoscopy. 1999;31:738-40.

6. Garcia Rodriguez JA, Montes Martinez I, Gómez Gonzalez JL, Ramos Macías A, López Alburquerque T. A case of malignant external otitis involving Klebsiella oxytoca. Eur J Clin Microbiol Infect Dis. 1992;11:75-7.

7. Garcia-Tsao G, Bosh J. Management of varices and variceal hemorrhage in cirrhosis. N Engl J Med. 2010;362:823-32.

8. Hoffmann KM, Deutschmann A, Weitzer C, Joaining M, Zechner E, Högenauer C, Hauer AC. Antibiotic-associated hemorrhagic colitis caused by cytotoxinproducing Klebsiella oxytoca. Pediatrics. 2010;125:e960-3.
9. Kulkarni SG, Parikh SS, Dhawan PS, Chachad H, Jambavalikar MB, Koppikar GV, Kalro RH. High frequency of bacteremia with endoscopic treatment of esophageal varices in advanced cirrhosis. Indian J Gastroenterol. 1999;18:143-5.

10. Lin OS, Wun SS, Chen YY, Soon MS. Bacterial peritonitis after elective endoscopic variceal ligation: a prospective study. Am J Gastroenterol. 2000;95:214-7.

11. Maluf-Filho F, Sakai P, Ishioka S, Matuguma SE. Endoscopic sclerosis versus cyanoacrylate endoscopic injection for the first episode of variceal bleeding: a prospective, controlled and randomized study in Child-Pugh class $\mathrm{C}$ patients. Endoscopy. 2001;33:421-7.

12. Maulaz EB, de Mattos AA, Pereira-Lima J, Dietz J. Bacteremia in cirrhotic patients submitted to endoscopic band ligation of esophageal varices. Arq Gastroenterol. 2003; $40: 167-72$.

13. Mauri D, Roumbkou S, Michalopoulou S, Tsali L, Spiliopoulou A, Panou C, Valachis A, Panagopoulos A, Polyzos NP. Port central venous catheters-associated bloodstream infection during outpatient-based chemotherapy. Med Oncol. 2009;27:1309-13.

14. Nelson DB. Infection control during gastrointestinal endoscopy. J Lab Clin Med. 2003;141:159-67.

15. Palazzo IC, d'Azevedo PA, Secchi C, Pignatari AC, Darini AL. Staphyloccocus hominis subsp. novobiosepticus strains causing nosocomial bloodstream infection in Brazil. J Antimicrob Chemother. 2008;62:1222-6.

16. Pascual J, Sureda A, Garcia-Hóz F, Erdozain JC, Perez-Hernandez F, Boixeda D. Spontaneous peritonitis due to Klebsiella oxytoca in a patient with cardiac ascites. Am J Gastroenterol. 1988;83:1313-4.

17. Rerknimitr R, Chanyaswad J, Kongkam P, Kullavanijaya P. Risk of bacteremia in bleeding and nonbleeding gastric varices after endoscopic injection of cyanoacrylate. Endoscopy. 2008;40:644-9.

18. Rogers KL, Fey PD, Rupp ME. Coagulase-negative staphylococcal infections. Infect Dis Clin North Am. 2009;23:73-98.

Received 26/3/2011 Accepted 24/5/2011 